\title{
Perceived Stigmatization Levels of Patients with Tuberculosis Applying to Tuberculosis Dispensaries in Istanbul
}

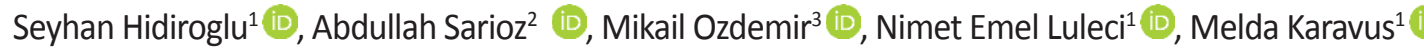 \\ ${ }^{1}$ Marmara University School of Medicine, Department of Public Health, İstanbul, Turkey \\ ${ }^{2}$ Ministry of Health, Van Edremit District Health Directorate, Van, Turkey \\ ${ }^{3}$ Ministry of Health, Osmaniye Tuberculosis Dispensary, Osmaniye, Turkey \\ Correspondence Author: Abdullah Sarioz \\ E-mail: a.sarioz@yahoo.com
}

Received: $21.11 .2017 \quad$ Accepted: 30.07 .2018

\begin{abstract}
Objective: In Turkey, tuberculosis (TB) is considered to be one of the formerly known social diseases. Similar researches exists for AIDS in many countries. There are very few publications about the tuberculosis stigma in our country at international level. This study aimed to assess tuberculosisrelated stigma levels and associated factors in patients with tuberculosis applying to tuberculosis dispensaries.

Methods: This descriptive study was conducted in two different tuberculosis dispensaries at Istanbul. We used the stigmatization scale for patients with tuberculosis to assess and compare stigma levels of our study population. Nonparametric statistical tests were used for comparison of stigma scores.

Results: In our study population, stigmatization because of tuberculosis was found to be related to low income, pulmonary involvement, occupation, and nonexistence of a relative with tuberculosis in the close environment.

Conclusion: Combating the causes of stigmatization can assist patients in accessing their healthcare provider. Patients would be more likely to abide by the treatment schedule, thus reducing tuberculosis resistance in the community and decreasing its spread.

Keywords: Dispensary, Istanbul, stigma, tuberculosis, Turkey
\end{abstract}

\section{INTRODUCTION}

Tuberculosis (TB) is a chronic, necrotizing infectious disease caused by Mycobacterium species and is transmitted to humans from other humans. According to the World Health Organization's 2016 report, the TB frequency was found to be 18 in 100,000 in Turkey (1). In addition to high morbidity and mortality rates, social effects of the disease such as absences from work and other social activities because of airborne transmission of the organism in active TB cases exist $(2,3)$.

In Turkey, TB is considered to be one of the formerly known social diseases. After Robert Koch described the tuberculosis bacilli, the illness gained a bad reputation, known as "ince hastalık," (i.e., "fragiles' disease") in Turkish. In Turkey, TB earned this social reputation with the belief that fragile people acquired it mostly because of deep sorrow. Even physicians would not actually tell a patient with TB, with the medical diagnostic name as "verem" (i.e., "tuberculosis"). Instead, the physician would express the diagnosis as "Ciğerlerinde duman var," i.e., "I detected smoke in your lungs." In addition, people required consolation to accept high mortality, with some even preferring death rather than the stigmatization of having "ince hastalık." The disease was so highly stigmatized that many scenarios regarding patients with TB appeared in movies and films (4-6).
In social sciences, stigmatization is a label that negatively affects a person's social identity and is defined as physical or behavioral characteristics that lead to the rejection of a person by the society. It presents in two forms: felt and internalized stigma (7). The experience of actual rejection, on the basis of that patients are not socially accepted, is called internalized stigmatization $(7,8)$. The embarrassing feeling of the patient himself because of having a stigmatized illness and the fear of being exposed is called felt stigmatization $(1,9)$.

There are several studies in the local language that describe the social dimensions of TB (10-12). Patients with TB are isolated from the society, depending on their own causes, and also by causes that originate from the society. Many patients are excluded and stigmatized by the society because of TB infection owing to long treatment durations and lack of knowledge regarding TB, together with fear and prejudice (13). Friends of patients with TB may stay away from them, and patients may be forced to separately eat and sleep at home. Besides this, patients often isolate themselves with the fear that they will infect or be humiliated by others (14).

Stigmatization delays diagnosis, aborts treatment, results in depression, and diminishes self-esteem $(2,15)$. All these conditions can lead to the development of drug resistance and increase treatment cost $(16,17)$. 
Investigating the stigmatization levels and accompanying conditions in TB-diagnosed patients may contribute to reducing stigma and indirectly increase treatment success, reduce costs, and increase the quality of life. We aimed to investigate the stigmatization status and associated factors of patients with TB in a group within the Turkish population.

\section{METHODS}

\subsection{Settings and study population}

This descriptive study was conducted in two different TB dispensaries in Istanbul between January and March 2015.

In Turkey, TB dispensaries are established to diagnose and treat patients with TB and establish prophylactic measures for their families. The first TB dispensary was established in Istanbul in 1923 and new dispensaries started to be opened nationwide (18). Directly observed treatment short course (DOTS) is used for TB treatment in our country (19) Medication is given free of charge to patients at dispensaries. The DOTS application strategy in Turkey is as follows. Patients who are nearby will visit the dispensary themselves and take their medication, whereas those who are far away from the dispensary are expected to visit the nearest health facility (health center, pharmacy, hospital, etc.) and take their medication there (20). Special training is given on DOTS therapy to particular health personnel (20)

Istanbul is the most crowded city in Turkey, and has immigrants from all over Turkey and even from other countries. Ethnically and socioeconomically, Istanbul shows a similar structure to Turkey as a whole (21). The city is divided into two main regions by the Bosphorus, one on the Anatolian side and the other on the European side.

The study population comprised 217 patients who applied to two TB dispensaries. There are 27 dispensaries in Istanbul. While choosing the two dispensaries sampling was not used. One dispensary on each side of the Istanbul Bosphorus gave us permission for collecting data, and thus, was included in our study. Patients with TB infection who completed their treatment and patients with active TB were included. No sample selection was made; attempts were made to contact the entire study population between January and March 2015. Among 217 patients, 203 patients were reached; 186 of these patients agreed to participate in the study.

\subsection{Data collection and Ethics}

Data collection was conducted using a face-to-face questionnaire. The stigmatization scale for patients with tuberculosis (SSPT) was used as a data collection tool along with the questions regarding sociodemographic characteristics. SSPT was developed by Sert (2010) (22). SSPT measures how stigmatized the patient perceives himself/herself. The Cronbach alpha coefficient of the scale is 0.91 . The scale had a total of 33 Likert-type questions that aims at measuring the perceived stigmatization level of patients with TB. Some questions $(2,4$, $17-19,22,23,25-28,30$ and 31) are scored in reverse. Scale is scored as "4" if participant absolutely participates that phrase, " 3 " if participating, " 2 " if not participating, " 1 " if absolutely not participating. As the perceived stigmatization level increases, the scale score is expected to increase. There are four subscales: stigmatization, self-perception, family-friend relationship, and internalized stigmatization. The highest score that could be obtained was 132, and the lowest score was 33.

Ethics approval for our study was granted by a local Ethical Committee. All procedures performed in this study that involved human participants were according to the ethical standards of the institutional and national research committee and the 1964 Helsinki Declaration and its later amendments or comparable ethical standards. Written informed consent was also provided from all the participants.

\subsection{Statistical analysis}

Kolmogorov Smirnov test was used for assessing normality assumption and found $\mathrm{p}<0.001$. Gaussian distributions could not be obtained therefore, the Mann-Whitney $U$ and Kruskal-Wallis tests were used for analyzing data. The Chisquare test was used for analyzing categorical data. The $\alpha$ error level for statistical significance was set at $5 \%$. Analyses were performed with IBM SPSS software version 20.

\section{RESULTS}

The study was completed with 186 patients, of which 76 were women and 110 were men. The sociodemographic characteristics of the participants is shown in Table 1 . When questioned, $26.9 \%$ of patients declared that they had low income, while no respondents indicated that they had high income. Nearly half of the participants $(40.3 \%)$ declared that they had no work. This was followed by the most frequently stated working status as being a permanent worker (26.3\%) (Table 1 ).

Table 1. Sociodemographic characteristics of participants

\begin{tabular}{|l|l|l|}
\hline \multicolumn{1}{|l}{} & $\mathrm{n}$ & $\%$ \\
\hline Sex & 76 & 40.9 \\
\hline Male & 110 & 59.1 \\
\hline Marital status & & \\
\hline Married & 110 & 59.1 \\
\hline Single/Other & 76 & 40.9 \\
\hline Education level (Graduated last school) & & \\
\hline Illiterate & 11 & 5.9 \\
\hline Below high school & 98 & 52.7 \\
\hline High school and above & 77 & 41.4 \\
\hline Living place & & \\
\hline Urban & 155 & 83.3 \\
\hline Rural & 31 & 16.7 \\
\hline Declared income level & & \\
\hline Low & 50 & 26.9 \\
\hline Middle & 136 & 73.1 \\
\hline Working status & & \\
\hline Own business/employer & 21 & 11.3 \\
\hline Permanent worker & 49 & 26.3 \\
\hline Officer & 23 & 12.4 \\
\hline Casual employee/temporary worker & 18 & 9.7 \\
\hline Not working & 75 & 40.3 \\
\hline & & \\
\hline
\end{tabular}


When the participants' results from the TB treatment were examined, it was observed that approximately half of the participants were healed. The proportion of individuals with complicated TB (chronic TB or TB with multiple drug resistance) was 3.8\%. Approximately three quarters of the participants were found to have pulmonary TB involvement. The proportions of individuals who had TB in their family or relatives who had TB within the previous year along with other descriptive data regarding patients are shown in Table 2.

Table 2. Descriptive data of participants with respect to tuberculosis

\begin{tabular}{|l|l|l|}
\hline & $n$ & $\%$ \\
\hline Treatment status & 51 & 27.4 \\
\hline $\begin{array}{l}\text { Still undergoing treatment } \\
\text { Complicated TB } \\
\text { Healed TB }\end{array}$ & 7 & 3.8 \\
\hline Other & 91 & 48.9 \\
\hline Location of TB involvement & 37 & 19.9 \\
\hline $\begin{array}{l}\text { Pulmonary } \\
\text { Extrapulmonary }\end{array}$ & 141 & 75.9 \\
\hline $\begin{array}{l}\text { There is someone living in the same house } \\
\text { having TB in the family/neighborhood-at the } \\
\text { time of study }\end{array}$ & 12 & 24.2 \\
\hline $\begin{array}{l}\text { There is someone living in another house with } \\
\text { TB in the family/neighborhood-at the time of } \\
\text { study }\end{array}$ & 3 & 6.5 \\
\hline $\begin{array}{l}\text { There is someone living in the same house with } \\
\text { TB in the family/neighborhood-previous year }\end{array}$ & 12 & 1.6 \\
\hline $\begin{array}{l}\text { There is someone living in another house with } \\
\text { TB in the family / neighborhood-previous year }\end{array}$ & 8 & 6.5 \\
\hline
\end{tabular}

All subscale and total scale scores were found to be higher in participants with low perceived income levels ( $p: 0.001$ for felt stigma subscale score, $p<0.001$ for other subscale and total scale scores) and in participants with pulmonary TB involvement ( $p<0.001$ for all). When stigma was examined according to the TB treatment status, all subscale and scale total scores were found to be lower in participants whose treatment was completed (felt stigma $p<0.001$, self perception $p: 0.030$, family friendship relationship p:0.003, internalized stigma p:0.007, total stigma p:0.001). According to the employment status, total scale and family friend relationship subscale scores were found higher in employees working as temporary workers than those with other employments ( $p: 0.014$ for all) (Table 3).

Felt stigma subscale, self-perception subscale, and total scale scores were found to be higher in patients with close relatives having TB at the time of the study (p:0.004, p:0.012 and $p: 0.006$, respectively). Scale scores were found to be similar in participants with a relative in the household having TB ( $p>0.05$ for all). In addition, scale scores were similar for patients with an acquaintance with TB within the previous year (Table 3).

Additional results of SSPT for the patients are shown in Table 3. There were no statistically significant differences between the stigmatization scores according to sex, marital status, education level, and location of residence. These data were not presented in the table form $(p>0.05)$.

Table 3. Distribution of stigma scale scores according to participant characteristics

\begin{tabular}{|c|c|c|c|c|c|c|c|c|c|c|}
\hline & $\begin{array}{l}\text { Felt stigma } \\
\text { score }\end{array}$ & la subscale & $\begin{array}{l}\text { Self-per } \\
\text { subscale }\end{array}$ & $\begin{array}{l}\text { rception } \\
\text { score }\end{array}$ & $\begin{array}{l}\text { Family-friend } \\
\text { subscale score }\end{array}$ & relationship & $\begin{array}{l}\text { Internaliz } \\
\text { subscale }\end{array}$ & $\begin{array}{l}\text { ed stigma } \\
\text { score }\end{array}$ & $\begin{array}{l}\text { Total st } \\
\text { score }\end{array}$ & tigma scale \\
\hline & Median & (Range) & Median & (Range) & Median & (Range) & Median & (Range) & Median & (Range) \\
\hline \multicolumn{11}{|l|}{ Declared income level } \\
\hline Low & 34 & $(21-44)$ & 18 & $(10-27)$ & 14 & $(8-20)$ & 19 & $(9-26)$ & 90 & $(60-114)$ \\
\hline Middle & 30 & $(21-44)$ & 14 & $(7-25)$ & 12 & $(6-20)$ & 16 & (9-27) & 77 & $(57-115)$ \\
\hline$p$ value ${ }^{a}$ & $0.001^{*}$ & & $<0.001^{*}$ & & $0.001^{*}$ & & $<0.001 *$ & & $<0.001^{*}$ & \\
\hline \multicolumn{11}{|l|}{ Working status } \\
\hline Own business/employer & 33 & $(23-44)$ & 16 & $(7-25)$ & 13 & (6-19) & 17 & $(10-27)$ & 78 & (59-107) \\
\hline Permanent worker & 31 & $(21-44)$ & 15 & $(9-27)$ & 12 & $(7-20)$ & 16 & $(9-25)$ & 77 & (57-115) \\
\hline Officer & 35 & $(22-42)$ & 14 & $(12-22)$ & 13 & $(8-20)$ & 19 & $(13-26)$ & 83 & (63-109) \\
\hline Casual employee/temporary worker & 32 & $(24-42)$ & 19 & $(12-23)$ & 15 & $(11-20)$ & 20 & $(13-25)$ & 91 & $(73-114)$ \\
\hline Not working & 30 & $(21-43)$ & 15 & $(7-23)$ & 12 & $(6-20)$ & 16 & $(9-26)$ & 77 & $(60-114)$ \\
\hline $\mathrm{p}$ value $^{\mathrm{b}}$ & 0.366 & & 0.053 & & $0.014^{*}$ & & 0.051 & & $0.014^{*}$ & \\
\hline \multicolumn{11}{|l|}{ Location of TB involvement } \\
\hline Pulmonary & 33 & (21-44) & 16 & $(7-27)$ & 13 & $(6-20)$ & 18 & (9-27) & 84 & (58-115) \\
\hline Extrapulmonary & 25 & $(21-41)$ & 14 & $(7-20)$ & 12 & (7-19) & 14 & $(10-20)$ & 66 & $(57-104)$ \\
\hline$p$ value ${ }^{a}$ & $<0.001^{*}$ & & $<0.001^{*}$ & & $<0.001^{*}$ & & $<0.001 *$ & & $<0.001^{*}$ & \\
\hline \multicolumn{11}{|l|}{ Treatment status } \\
\hline Still receiving treatment & 31 & $(23-42)$ & 16 & $(9-21)$ & 13 & $(6-19)$ & 17 & $(9-25)$ & 79 & $(58-115)$ \\
\hline Complicated TB & 33 & $(26-43)$ & 16 & $(12-23)$ & 15 & $(12-19)$ & 18 & $(13-25)$ & 89 & $(71-114)$ \\
\hline Healed TB & 26 & $(21-44)$ & 14 & $(7-27)$ & 12 & $(7-20)$ & 15 & $(10-27)$ & 70 & (57-114) \\
\hline Other & 37 & $(24-43)$ & 17 & $(7-23)$ & 13 & $(6-20)$ & 20 & $(9-25)$ & 87 & $(62-110)$ \\
\hline$p$ value ${ }^{b}$ & $<0.001^{*}$ & & $0.030 *$ & & $0.003^{*}$ & & $0.007^{*}$ & & $0.001 *$ & \\
\hline \multicolumn{11}{|c|}{ There is someone living in the same house with TB in the family / neighborhood-at the time of study } \\
\hline Yes & 24 & $(22-35)$ & 14 & $(12-17)$ & 12 & $(10-15)$ & 14 & $(13-18)$ & 67 & (63-89) \\
\hline No & 32 & $(21-44)$ & 16 & $(7-27)$ & 13 & $(6-20)$ & 17 & $(9-27)$ & 81 & (57-115) \\
\hline p value a & $0.004^{*}$ & & $0.012^{*}$ & & 0.091 & & 0.051 & & $0.006 *$ & \\
\hline
\end{tabular}

${ }^{\mathrm{a}}$ Mann-Whitney $\mathrm{U}$ test, ${ }^{\mathrm{b}}$ Kruskal-Wallis test, * Statistically significant 


\section{DISCUSSION}

TB is not only an infectious disease but also a public health problem that has physical, social, and psychological dimensions. Patients may be exposed to stigmatization for reasons such as long treatment duration and incorrect beliefs from the previous period of modern therapy. Stigmatization is an additional psychological burden on patients $(23,24)$.

In our study, there was no significant difference in terms of stigma levels between sexes; these results are different from those reported in the literature. Suleiman et al (25) also indicated that there was no difference in TB stigma according to sex. In another study in Bangladesh, higher mean index values for stigma were reported in women than in men, possibly because of cultural factors and the situation of women in the society (26).

Stigmatization levels were found to be higher in individuals who reported low income, possibly because of the direct effect of the income on stigma, as well as the coexistence of the low income education levels (27). However, no significant difference was found between the scale scores according to educational level. Coreil et al (28) stated that the felt stigma was influenced by economic level and many other factors. Moreover, the stigma level was higher in individuals with low income. Chowdhury et al (29) also reported that stigma levels were higher in individuals with low income. Soomro et al (30) reported that tuberculous stigma was more clearly experienced by patients with low incomes who had lost their jobs and had financial distress. Attitudes of societies to low-income individuals may also be a contributing factor to stigmatization. The low income level and the coexistence of carrying an infectious disease may have caused the stigma to be felt at a higher level in these patients.

In our study, patients with pulmonary TB were stigmatized at a higher level than those with extrapulmonary TB. Tuberculosis with other visceral involvement may be felt to be less stigmatizing than pulmonary tuberculosis because of the lower incidence of infectivity and greater acceptability as an ordinary disease. Also in extrapulmonary TB, findings are less noticeable than pulmonary TB; this may also reduce stigmatization levels. Park et al (31) showed that patients with extrapulmonary TB were more compatible with drug treatment in their studies, suggesting that extrapulmonary TB is not observed as a stigmatizing condition but as an ordinary disease by patients. Chowdhury et al (29) also found that stigma in patients with pulmonary TB was higher than those with extrapulmonary TB.

We also found that the presence of another person with TB in the same house at the time of study was found to reduce stigmatization. An explanation for this could be that the patients with a relative in the same situation in the immediate vicinity normalizes the psychological dimension of the disease (32) Also while family-friend relationships (family-friend relationships subscores) were significantly affected by all other variables (like income level, working status or location of TB involvement etc.), this relationship was maintained in patients who have a relative with TB. This is a finding that supports patients who have similar diseases in their vicinity and find tuberculosis more acceptable. Wieland et al (33) also reported that stigmatization in patients with TB caused concealment, embarrassment, fear, and isolation. Even if a disease is stigmatizing, it may be more easily accepted by patients in the presence of an acquaintance having the illness and living in close vicinity of the patient.

Total stigma levels were found to be higher in temporary workers than in those in other occupational groups. In addition, family friendships were also more affected in this group. Temporary workers often work collectively and in crowded groups at their workplaces. Therefore, they are more likely to be stigmatized by their societies because of the disease symptoms. Ozturk and Hisar (24) revealed that stigma scores were found to be higher in employees working at their jobs than civil servants and housewives. The reason for the different results between previous studies may be that employees such as temporary workers were not involved in the study groups of the mentioned research. However, in our study, the stigma levels were higher in temporary workers than those who had no work.

The limitations of the study include the fact that multivariate analyses could not performed because of data characteristics and the independent effects of factors that affect stigma could not be investigated. Another limitation is that the results of our study could not be generalized to all TB patients who admitted to dispensaries since study conducted at only two dispensaries.

\section{CONCLUSION}

TB stigmatization was found to be related to low income, pulmonary involvement, occupation, and nonexistence of a relative with TB in the close environment. Combating the causes of stigmatization can assist patients in accessing their healthcare provider and encouraging compliance of the treatment schedule, thereby reducing TB resistance in the community and decreasing its spread. Furthermore, individuals will seek medical care earlier and receive better treatment with fewer complications. Qualitative studies are recommended to examine the causes of stigmatization in patients with TB more deeply.

Conflict of Interest: Authors declare no conflict of interest

Financial Disclosure: Nothing to disclose

\section{REFERENCES}

[1] World Health Organization. Global tuberculosis report-2016. Geneva, Switzerland: WHO, 2016. Available from: http://apps. who.int/iris/bitstream/10665/250441/1/978.924.1565394eng.pdf?ua=1.

[2] Mason PH, Degeling C, Denholm J. Sociocultural dimensions of tuberculosis: an overview of key concepts. Int J Tuberc Lung Dis. 2015; 19:1135-43. 
[3] Zhang T, Liu X, Bromley H, Tang S. Perceptions of tuberculosis and health seeking behaviour in rural Inner Mongolia, China. Health Policy 2007; 81:155-65.

[4] Açikel GY, Pakyüz SÇ. Evaluating the Stigma on Patients with Tuberculosis. FNJN 2015; 23:136-45.

[5] Şimşek H, Özmen D, Çetinkaya AÇ. Evaluation internalized stigma of tuberculosis patients. Uluslararasi Hakemli Hemşirelik Araştirmalari Dergisi 2016; (Turkish) 7:156-73.

[6] Vidinel i. A historical overview of tuberculosis in Turkey. In: Özkara Ş, Kılıçaslan Z, editors. Tuberculosis. İstanbul: Türk Toraks Derneği Yayınları; 2010; (Turkish) 17-24.

[7] Major B, O'Brien LT. The social psychology of stigma. Annu Rev Psychol. 2005; 56: 393-421.

[8] Corrigan PW, Penn DL. Lessons from social psychology on discrediting psychiatric stigma. Am Psychol 1999; 54: 765-76.

[9] Aslan D. A socially stigmatizing disease from a public health perspective: Tuberculosis. Klinik Gelişim Dergisi 2006; (Turkish) 20: 86-90.

[10] Özkurt S, Kalkan Oğuzhanoğlu N, Özdel O, Altın R, Balkanlı H, Konya T. Evaluation of Compliances of Tuberculous Cases to Treatment and Social Life. Tuberk Toraks 2000; 48: 213-18.

[11] Taşkın F, Olgun N. Quality of life in patients with pulmonary tuberculosis. Turk Toraks Derg 2010; 11: 19-25.

[12] Aslan D, Altıntaş H, Emri S, Cesuroğlu T, Kotan O, Koyuncu $S$, et al. Self-evaluations of tuberculosis patients about their illnesses at Ankara Atatürk Sanatorium Training and Research Hospital, Turkey. Respiratory Medicine 2004; 98:626-31.

[13] Chang SH, Cataldo JK. A systematic review of global cultural variations in knowledge, attitudes and health responses to tuberculosis stigma. Int J Tuberc Lung Dis. 2014; 18:168-73.

[14] Macq J, Solis A, Martinez G, Martiny P, Dujardin B. An exploration of the social stigma of tuberculosis in five "municipios" of Nicaragua to reflect on local interventions. Health policy 2005; 74:205-17.

[15] Kumar BA. Rehabilitation of treated TB patients: Social, psychological and economic aspects. Int J Mycobacteriol 2016; 5:129-30.

[16] Karagöz T, Arda H, Erboran T, Kiliçaslan Z, Çağlar E, Erem AR. Evaluation of Istanbul dispensary studies in terms of diagnosis, treatment and follow-up of new cases of pulmonary tuberculosis. Tüberküloz ve Toraks Dergisi 2000; 48:128-35.

[17] Wright A, Zignol M, Van Deun A, Falzon D, Gerdes SR, Feldman K, Hoffner S, Drobniewski F, Barrera L, van Soolingen D, Boulabhal F, Paramasivan CN, Kam KM, Mitarai S, Nunn P, Raviglione M. Epidemiology of antituberculosis drug resistance 2002-07: an updated analysis of the Global Project on Anti-Tuberculosis Drug Resistance Surveillance. The Lancet 2009; 373:1861-73.

[18] Aksu M. Tuberculosis in Turkey in terms of the history of medicine. Ankara: Türkiye Ulusal Verem Savaşı Dernekleri Federasyonu, 2007; (Turkish) 161-70.
[19] World Health Organization. What is DOTS (Directly Observed Treatment, Short Course). Available from: http://www.searo. who.int/tb/topics/what_dots/en/.

[20] Özkara Ş, Arpaz S, Özkan S, Aktaş Z, Örsel O, Ecevit H. Directly Observed Treatment in the Treatment of Tuberculosis (DOT). Ankara: Türkiye Ulusal Verem Savaşı Dernekleri Federasyonu; 2002. (Turkish) Available from: http://www.verem.org.tr/pdf/ dgt1.pdf.

[21] Turkish Statistical Institute. Istanbul-2013 with selected indicators. Istanbul, Turkey: TUIK. (Turkish) Available from: http://www.tuik.gov.tr/ilGostergeleri/iller/ISTANBUL.pdf

[22] Sert H. Evaluation of Stigma In Tuberculosis Patients. M.U. Institute of Health Sciences, Doctoral Thesis. 2010.

[23] Şimşek H, Özmen D, Çakmakçı-Çetinkaya A. Evaluation internalized stigma of tuberculosis patients. International Refereed Journal of Nursing Researches. 2016; 7:156-73.

[24] Ozturk FO, Hisar F. Stigmatisation of tuberculosis patients. Int J Community Med Public Health. 2014; 1:37-43.

[25] Ahmed Suleiman MM, Sahal N, Sodemann M, El Sony A, Aro AR. Tuberculosis stigma in Gezira State, Sudan: a case-control study. Int J Tuberc Lung Dis. 2013; 17:388-93.

[26] Somma D, Thomas BE, Karim F, Kemp J, Arias N, Auer C, Gosoniu GD, Abouihia A, Weiss MG. Gender and socio-cultural determinants of TB-related stigma in Bangladesh, India, Malawi and Colombia. Int J Tuberc Lung Dis. 2008; 12:856-66.

[27] Courtwright A, Turner AN. Tuberculosis and stigmatization: pathways and interventions. Public Health Rep 2010; 125:34-42.

[28] Coreil J, Mayard G, Simpson KM, Lauzardo M, Zhu Y, Weiss $M$. Structural forces and the production of TB-related stigma among Haitians in two contexts. Soc Sci Med 2010; 71:1409-17.

[29] Chowdhury MR, Rahman MS, Mondal MN, Sayem A, Billah B. Social Impact of Stigma Regarding Tuberculosis Hindering Adherence to Treatment: A Cross Sectional Study Involving Tuberculosis Patients in Rajshahi City, Bangladesh. Jpn J Infect Dis 2015; 68: 461-6.

[30] Soomro MH, Qadeer E, Morkve O. Barriers in the management of tuberculosis in rawalpindi, Pakistan: a qualitative study. Tanaffos 2013; 12:28-34.

[31] Park CK, Shin HJ, Kim YI, Lim SC, Yoon JS, Kim YS, Kim JC, Kwon YS. Predictors of Default from Treatment for Tuberculosis: a Single Center Case-Control Study in Korea. J Korean Med Sci 2016; 31:254-60.

[32] Robbins JM, Kirmayer LJ. Attributions of common somatic symptoms. Psychol Med 1991; 21:1029-45.

[33] Wieland $M L$, Weis JA, Olney $M W$, Alemán $M$, Sullivan $S$, Millington K, O'Hara C, Nigon JA, Sia IG. Screening for tuberculosis at an adult education center: results of a community-based participatory process. Am J Public Health 2011; 101:1264-67.

How to cite this article: Hidiroglu S., Sarioz A., Ozdemir M., Luleci N. E., Karavus M. Perceived Tuberculosis Stigma in Istanbul. Clin Exp Health Sci 2019; DOI: 10.33808/marusbed.546574 